\title{
PENINGKATAN KEMAMPUAN MELIPAT DENGAN MEDIA KERTAS WARNA-WARNI PADA ANAK
}

\author{
Tri Wiyati \\ TK Dharma Wanita I Malebo Kandangan Temanggung \\ Email : triwiyatitmg@gmail.com
}

\begin{abstract}
Abstrak
Tujuan dari penelitian ini adalah untuk mengetahui cara meningkatkan kemampuan melipat dan besarnya peningkatan kemampuan melipat dengan media kertas warna-warni pada anak Kelompok B TK Dharma Wanita I Malebo Kandangan Temanggung Semester II Tahun Pelajaran 2017/2018. Subyek penelitian ini adalah peserta didik Kelompok B TK Dharma Wanita I Malebo berjumlah 17 anak. Pelaksanaan penelitian pada bulan April 2018. Metode pengumpulan data yang digunakan adalah observasi, dokumentasi dan wawancara.

Berdasarkan hasil pengamatan dan analisis data yang diperoleh dari tindakan perbaikan pembelajaran antar siklus dalam penelitian tindakan kelas yang dilakukan melalui pembelajaran dapat ditarik kesimpulan bahwa dengan menggunakan media kertas warna-warni dapat meningkatkan kemampuan melipat pada anak Kelompok B TK Dharma Wanita I Malebo Kandangan Temanggung. dengan dibuktikan adanya hasil diskriptif persentase ketuntasan belajar yaitu dari kondisi awal jumlah anak yang mendapat kriteria penilaian berkembang sesuai harapan sebanyak 4 anak atau 23,5\%, meningkat menjadi 8 anak atau $47 \%$ pada Siklus I, dan pada Siklus II meningkat sebanyak 10 anak atau 58,8\% dengan kriteria penilaian berkembang sesuai harapan dan 5 anak atau 29,4\% dengan penilaian berkembang sangat baik, ditandai dengan anak mampu melipat kertas mengikuti petunjuk lebih dari 7 lipatan dan mampu melipat kertas menjadi bentuk sederhana dengan rapi.
\end{abstract}

Kata kunci : kemampuan melipat, media kertas warna-warni

Abstract

The purpose of this study was to find out how to increase the folding ability and the magnitude of the increase in folding ability with colorful paper media in children of the Dharma Wanita I Kindergarten Malebo Kandangan B Group Temanggung Semester II 2017/2018 Academic Year. The subjects of this study were 17 students of Group B of Dharma Wanita I Kindergarten, Malebo. Implementation of research in April 2018. Data collection methods used were observation, documentation and interviews. Based on the results of observations and analysis of data obtained from inter-cycle learning corrective actions in classroom action research conducted through learning it can be concluded that using colorful paper media can improve the folding ability of children in the Group B Dharma Wanita I Kindergarten Malebo Kandangan Temanggung. with proven evidence of the percentage of completeness of learning that is from the initial conditions the number of children who received the assessment criteria developed according to expectations as many as 4 children or 23.5\%, increased to 8 children or $47 \%$ in Cycle I, and in Cycle II increased by 10 children or $58.8 \%$ with the assessment criteria developed according to expectations and 5 children or $29.4 \%$ with very good ratings developed, marked by the child being able to fold paper following instructions of more than 7 folds and being able to fold paper into a neat simple form.

Keywords: ability to fold, colorful paper media

(C) 2019 Tri Wiyati

Under the license CC BY-SA 4.0

http://jurnal.upmk.ac.id/index.php/pelitapaud 


\section{PENDAHULUAN}

Aspek perkembangan motorik bertujuan untuk memperkenalkan dan melatih gerakan kasar dan halus, meningkatkan kemampuan mengelola, mengontrol gerakan tubuh dan koordinasi, serta meningkatkan keterampilan tubuh dan cara hidup sehat sehingga dapat menunjang pertumbuhan jasmani yang kuat, sehat dan terampil. Motorik merupakan perkembangan pengendalian gerakan tubuh melalui kegiatan yang terkoordinir antara susunan saraf, otot dan otak. Perkembangan motorik meliputi motorik kasar dan motorik halus. Motorik kasar adalah gerakan tubuh yang menggunakan otot-otot besar atau sebagian besar atau seluruh anggota tubuh yang dipengaruhi oleh kematangan anak itu sendiri, sedangkan motorik halus adalah gerakan yang menggunakan otot-otot halus atau sebagian anggota tubuh tertentu yang dipengaruhi oleh kesempatan belajar dan berlatih. Kedua kemampuan tersebut sangat penting agar anak bisa berkembang secara optimal.

Perkembangan motorik sangat dipengaruhi oleh organ otak. Semakin matangnya perkembangan sistem saraf otak yang mengatur otot, memungkinkan berkembangnya kompetensi atau kemampuan motorik anak. Dalam proses perkembangan anak, motorik kasar berkembang lebih dahulu dibandingkan dengan motorik halus. Hal ini terbukti bahwa anak sudah dapat menggunakan otot-otot kakinya untuk berjalan sebelum anak mampu mengontrol tangan dan jarijarinya untuk menggambar, menggunting atau menulis. Pada awal perkembangan dan pengalamaan anak kemampuan motorik tersebut berkembang dari tidak koordinasi dengan baik menjadi terkoordinasi secara baik. Prinsip utama perkembangan motorik adalah pematangan urutan, motivasi, pengalaman dan latihan atau praktek.

Berdasarkan hasil penelitian pada beberapa sekolah di Temanggung bahwa perkembangan motorik halus anak Taman Kanak-kanak ditekankan pada koordinasi gerakan motorik halus dalam hal ini berkaitan dengan kegiatan meletakkan atau memegang suatu objek dengan menggunakan jari tangan. Pada usia 4 tahun koordinasi gerakan motorik halus anak sangat berkembang bahkan hampir sempurna. Pada usia 5 atau 6 tahun koordinasi gerakan motorik halus anak berkembang pesat. Pada masa ini anak sudah mampu mengkoordinasikan gerakan visual motorik seperti mengkoordinasikan gerakan mata dengan tangan, lengan dan tubuh secara bersamaan. Kemampuan 
motorik halus terkait dengan perkembangan fleksibilitas tangan dan jari jemari untuk melakukan aktifitas seperti makan, menulis, menggambar, mencocok bentuk, meronce, menggunting, melipat, memakai pakaian dan juga bermain dengan permainan yang membutuhkan koordinasi tangan.

TK Dharma Wanita I Malebo Kandangan Temanggung sebagai salah satu lembaga pendidikan formal yang mendidik anak usia dini, mengalami beberapa masalah yang terkait dengan kegiatan belajar mengajar. Di sekolah ini masih ada beberapa anak dengan kemampuan motorik halus rendah. Rendahnya kemampuan motorik halus anak terlihat dari banyaknya anak yang belum dapat membuat tulisan dengan baik, belum dapat melipat kertas menjadi sebuah karya seni dengan rapi. Hal ini karena anak belum dapat menggunakan media pembelajaran dengan baik dan benar sehingga anak mengalami kesulitan dalam mengkoordinasikan gerakan tangan dan jari-jari secara fleksibel.

Pada pengembangan motorik halus anak selama ini guru lebih menekankan pada kegiatan menulis dan menggambar saja. Anak yang belum bisa menggunakan alat tulis dengan baik akan merasa cepat bosan dan malas. Hal ini karena kegiatan yang diberikan kurang bervariasi dan kurang menumbuhkan semangat anak. Kegiatan-kegiatan yang disampaikan sebagai materi hendaknya disesuaikan dengan kemampuan anak dan tidak hanya sekedar sebagai pelengkap materi.

Dalam kegiatan motorik halus agar anak tidak menjadi bosan dan malas mengerjakan, media-media yang digunakan harus bisa menarik perhatian anak dan tidak membahayakan anak. Dengan banyaknya media yang ada, guru yang harus bisa menyesuaikan dengan tahap perkembangan anak. Banyak cara yang dapat dilakukan untuk meningkatkan motorik halus anak, diantaranya adalah dengan kegiatan seni melipat kertas. Seni melipat kertas dapat melatih motorik halus anak melalui koordinasi gerakan tangan dan jari-jari. Melalui kegiatan seni melipat kertas anak seolah dituntut untuk menjadi lebih tekun, telaten dan teliti tanpa merasa bosan. Seni melipat kertas sangat menyenangkan sehingga semakin tinggi ketelitian dan kreativitasnya semakin baik dan menarik pula bentuk yang dihasilkan. Dengan pembelajaran seni melipat kertas yang diberikan secara benar diharapkan kemampuan motorik anak dapat meningkat khususnya kemampuan motorik halusnya.

Dari hasil observasi yang dilakukan sebelum dilakukan perbaikan pembelajaran 
pada anak Kelompok B TK Dharma Wanita I Malebo yang berjumlah 17 anak, yang mampu melipat kertas sehingga menghasilkan bentuk lipatan yang baik baru mencapai 4 anak atau 23,5\%, sedangkan sisanya sebanyak 13 anak atau 76,5\% masih memerlukan bimbingan dan motivasi dari guru karena anak merasa kesulitan melipat bentuk sehingga anak malas dan tidak dapat menyelesaikan tugas melipat yang diberikan oleh guru.

\section{METODE PENELITIAN}

\section{Jenis Penelitian}

Metode yang digunakan dalam penelitian ini adalah Penelitian Tindakan Kelas (Classroom Action Research). Implikasi dalam penelitian tindakan ini dilakukan secara kolaborasi artinya peneliti dapat berkolaborasi atau bekerjasama dengan guru.

\section{Tempat Penelitian}

Lokasi penelitian tindakan kelas ini dilakukan di TK Dharma Wanita I Malebo Kecamatan Kandangan Kabupaten Temanggung Provinsi Jawa Tengah.

\section{Waktu Penelitian}

Penelitin tindakan kelas ini dilaksanakan pada Semester II tahun pelajaran 2017/2018, tepatnya pada bulan April 2018

\section{Subjek Penelitian}

Subyek penelitian merupakan peserta didik yang dikenai tindakan yaitu semua anak kelompok B TK Dharma Wanita I Malebo Kandangan Temanggung yang berjumlah 17 anak yang terdiri dari 7 anak laki-laki dan 10 anak perempuan dengan melibatkan 1 orang guru sebagai observer.

\section{Data dan Sumber Data}

Sumber data dibedakan atas data primer dan data sekunder. Sumber data primer adalah objek yang diobservasi langsung yang dilakukan di Kelompok B TK Dharma Wanita I Malebo dan para informan atau pemberi informasi yang diwawancarai yaitu anak Kelompok B dan guru. Sumber data sekunder berupa dokumentasi dan arsip-arsip resmi yang dapat mendukung hasil penelitian yang diperoleh dari hasil raport, daftar penilaian, dan daftar hadir anak.

\section{Teknik dan Alat Pengumpulan Data}

Observasi

Observasi adalah kegiatan pengamObservasi adalah kegiatan pengamatan (pengambilan data) untuk memotret seberapa jauh efek tindakan telah mencapai sasaran (Supardi, 2009:127). Kegiatan observasi dilakukan selama kegiatan pembelajaran berlangsung, sehingga perubahan-perubahan yang terjadi setelah dilakukan tindakan akan 
dapat diketahui dalam observasi ini. Dengan kata lain, dalam kegiatan pengamatan observer menuliskan berbagai kegiatan yang terjadi di dalam kelas, baik kegiatan yang dilakukan oleh siswa, guru, ataupun perubahan yang terjadi di dalam kelas.

Dalam penelitian ini, observasi dilakukan untuk mengetahui peningkatan kemampuan melipat anak melalui kegiatan melipat dengan kertas warna-warni. Instrumen penelitian yang digunakan berupa lembar/panduan observasi yang telah disusun sebelumnya.

Dokumentasi

Dokumentasi merupakan catatan suatu peristiwa yang sudah terjadi yang berupa tulisan, gambar-gambar atau video yang direkam oleh seseorang dan digunakan sebagai data sebagai hasil pengamatan. Metode dokumentasi dalam penelitian ini berupa foto-foto hasil kerja anak yang dapat menggambarkan mengenai peningkatan motivasi belajar anak. Dokumentasi tersebut berbentuk daftar penilaian. Dokumentasi dilakukan saat observasi, pengambilan foto-foto tersebut bertujuan agar data yang diperoleh yakni yang berupa fakta-fakta peristiwa proses pembelajaran dapat optimal, sehingga dapat dijadikan sebagai bukti, selain itu dapat dijadikan sebagai bahan evaluasi. Dokumentasi dalam penelitian ini berupa RPPH, buku penilaian, dan buku anekdot record pada kegiatan pembelajaran melipat.

Wawancara

Wawancara adalah metode pengumpulan data dengan jalan bertanya untuk mendapatkan informasi dengan cara bertanya secara langsung kepada responden. Wawancara digunakan untuk menggali data secara mendalam. Wawancara dalam penelitian ini digunakan untuk memperoleh informasi tentang pembelajaran kegiatan harian terutama dalam meningkatkan kemampuan melipat anak Kelompok B TK Dharma Wanita I Malebo dan tanggapan guru sebelum dan sesudah selesai diadakan tindakan dengan kegiatan melipat.

\section{Analisa Data}

Analisis data adalah suatu proses mengolah dan menginterpretasi data dengan tujuan untuk menundukkan berbagai informasi sesuai dengan fungsinya hingga memiliki makna dan arti yang jelas sesuai dengan tujuan penelitian (Wina Sanjaya, 2011: 106). Analisis data dalam PTK diarahkan untuk mencari dan menemukan upaya yang dilakukan guru dalam meningkatkan kualitas proses dan hasil belajar anak. Penelitian 
inimenganalisis data dengan deskriptif kualitatif dan kuantitaf.

Analisis data kuantitaf digunakan untuk menentukan peningkatan hasil belajar anak sebagai pengaruh dari setiap tindakan yang dilakukan guru (Wina Sanjaya, 2011: 106). Data kuantitatif dapat diperoleh peneliti dengan instrumen lembar observasi yang telah ditentukan oleh peneliti. Instrumen ini untuk mendeskriptifkan hasil penelitian secara statistik. Langkah-langkah analisis komporatif yaitu memberikan nilai pada setiap hasil pengamatan. Membuat tabulasi nilai observasi kemampuan melipat anak . Menjumlahkan skor yang dicapai anak pada setiap butir pengamatan. Menghitung persentase pencapaian peningkatan kemampuan melipat. Menghitung hasil rata-rata pencapaian dengan skor maksimum pada setiap siklus yang telah ditentukan. Membandingkan hasil persentase pencapaian pada setiap anak dengan persentase keberhasilan pada setiap siklus yang telah ditentukan.

Indikator Keberhasilan

Indikator keberhasilan dalam penelitian ini adalah ditandai dengan meningkatnya kemampuan melipat pada anak. Peneliti menentukan indikator keberhasilan yaitu dengan persentase rata- rata $80 \%$ anak mampu menunjukkan kemampuan melipat yang baik.

Tabel 1. Indikator Keberhasilan

\begin{tabular}{|c|c|c|c|c|c|}
\hline \multirow[t]{2}{*}{ No } & \multirow[t]{2}{*}{ Indikator } & \multicolumn{4}{|c|}{ Penilaian } \\
\hline & & $\mathrm{BB}$ & MB & BSH & $\begin{array}{c}\text { BS } \\
\text { B }\end{array}$ \\
\hline 1 & $\begin{array}{l}\text { Anak mampu } \\
\text { melipat kertas } \\
\text { mengikuti } \\
\text { petunjuk lebih } \\
\text { dari } 7 \text { lipatan }\end{array}$ & & & & \\
\hline 2 & $\begin{array}{l}\text { Anak mampu } \\
\text { melipat kertas } \\
\text { menjadi bentuk } \\
\text { sederhana } \\
\text { dengan rapi }\end{array}$ & & & & \\
\hline
\end{tabular}

Keterangan :

BB : Belum Berkembang

MB : Mulai Berkembang

BSH : Berkembang Sesuai Harapan

BSB : Berkembang Sangat Baik

\section{Prosedur Penelitian}

Perencanaan Tindakan

Peneliti menjelaskan tentang indikator dan tujuan pembelajaran . Peneliti memberikan apersepsi kepada anak. Peneliti membagi anak menjadi 4 kelompok. Peneliti mempersiapkan peralatan yang diperlukan. Anak melakukan kegiatan melipat sesuai dengan petunjuk peneliti. Anak diberi kesempatan untuk bertanya apabila belum paham. Anak mengumpulkan hasil melipat yang telah dibuatnya. Peneliti dan anak membahas hasil karya melipat anak.

Pelaksanaan Tindakan

Pertemuan pertama Siklus I dilaksanakan hari Senin tanggal 9 April 
2018 dengan kegiatan awal berdoa, apersepsi tentang tema pembelajaran, menyanyi, menghafal surat pendek dan salam. Pembelajaran pada kegiatan inti yaitu peneliti menjelaskan kegiatan melipat kertas membuat bentuk rumah, pemberian tugas meniru pola gambar, menggunting pola gambar, dan membilang dengan papan pasak. Pada kegiatan akhir, peneliti melakukan evaluasi tanya jawab tentang pembelajaran yang telah dilaksanakan dalam sehari.

Pertemuan kedua Siklus I dilaksanakan pada hari Kamis tanggal 12 April 2018 dengan kegiatan awal berdoa, salam, absensi anak, menghafal surat pendek dan berbagi cerita. Pembelajaran pada kegiatan inti yaitu peneliti menjelaskan kegiatan melipat kertas membuat bentuk baling-baling, kemudian dilanjutkan dengan mengelompokkan kata benda, menggambar dan bercerita, membaca buku dongeng. Selama kegiatan pembelajaran, peneliti memberi bimbingan dan motivasi kepada anak. Kegiatan pembelajaran diakhiri dengan evaluasi dan tanya jawab tentang kegiatan yang telah dilaksanakan.

Pertemuan pertama Siklus II dilaksanakan pada hari Senin 19 April 2018 dengan kegiatan awal berdoa, apersepsi, menyanyi, senam dan masuk kelas. Kegiatan inti yang dilakukan adalah peneliti menjelaskan tentang cara melipat kertas membentuk bunga tulip kemudian anak dipersilakan untuk mengikuti cara melipat membuat bunga tulip dan membei hiasan pada hasil lipatan. Setelah kegiatan melipat selesai, pembelajaran dilanjutkan menghubungkan gambar dengan angka, menulis sederhana dan menceritakan hasil karya anak. Kegiatan diakhiri dengan mengulas kegiatan sehari, pesan-pesan, salam, doa pulang. Pertemuan kedua Siklus II dilaksanakan pada hari Kamis 22 April 2018 dengan kegiatan awal berdoa, salam, absensi anak dan menyanyi. Kegiatan inti yaitu melipat kertas membuat bentuk ikan kemudian dihiasi dengan memberikan coretan berupa gambar mata, hidung, mulut. Kegiatan inti dilanjutkan dengan menggambar dan bercerita, menghubungkan gambar ikan dengan kartu kata ikan, membaca buku cerita. Kegiatan diakhiri dengan mengulas kegiatan sehari, pesan-pesan, salam dan doa pulang.

\section{Observasi}

Kegiatan observasi ini dilakukan selama proses belajar mengajar berlangsung sampai dengan selesai, untuk mengetahui aktivitas belajar anak selama proses pembelajaran melalui kegiatan melipat. Selama proses belajar mengajar berlangsung, peneliti melakukan 
pengamatan terhadap kegiatan anak dalam pembelajaran menggunakan lembar observasi dibantu teman sejawat.

Refleksi

Refleksi merupakan langkah mengingat kembali kegiatan yang sudah dilakukan oleh anak dan peneliti. Lembar observasi yang telah diisi tersebut kemudian diolah dengan cara menganalisis dan mengevaluasi yang bertujuan untuk mengetahui apakah pada kegiatan tersebut ditemui kesulitan pada anak sehingga hasilnya belum optimal. Kesulitan itu akan dikaji lagi dan dikaitkan dengan teori-teori yang relevan untuk mendapatkan hasil yang optimal. Setelah mengkaji, menganalisis, dan mengevaluasi pada Siklus I peneliti menindaklanjutinya dengan melakukan penelitian di Siklus II.

Pada Siklus ke II akan diketahui mengenai hasil apakah sudah maksimal atau belum. Apabila pada Siklus II hasil yang diharapkan belum maksimal, maka penelitian dapat dilanjutkan pada siklus berikutnya sampai dengan hasil yang diharapkan optimal sesuai dengan indikator yang telah ditetapkan.

\section{HASIL PENELITIAN}

DAN

\section{PEMBAHASAN}

\section{Hasil Penelitian}

Kondisi Awal

Peneliti melakukan pengamatan terhadap tingkat kemampuan melipat anak sebagai langkah awal sebelum diadakan penelitian tindakan kelas. Hasil yang diperoleh pada kemampuan awal sebelum tindakan pada akhirnya akan dibandingkan dengan hasil setelah tindakan melalui kegiatan melipat kertas warna-warni. Perbandingan bertujuan untuk menunjukkan adanya peningkatan sebelum dan sesudah dilakukan tindakan. Pada tahap ini peneliti melakukan bimbingan dan stimulasi untuk mengoptimalkan kemampuan melipat pada anak Kelompok B TK Dharma Wanita I Malebo Kandangan Temanggung.

Tabel 2 Kondisi Awal Sebelum Penelitian

\begin{tabular}{llcc}
\hline No & Penilaian & $\begin{array}{c}\text { Jumlah } \\
\text { Anak }\end{array}$ & Persentase \\
\hline 1 & BB & 11 & $64,7 \%$ \\
2 & MB & 2 & $11,8 \%$ \\
3 & BSH & 4 & $23,5 \%$ \\
4 & BSB & 0 & $0 \%$ \\
\hline
\end{tabular}




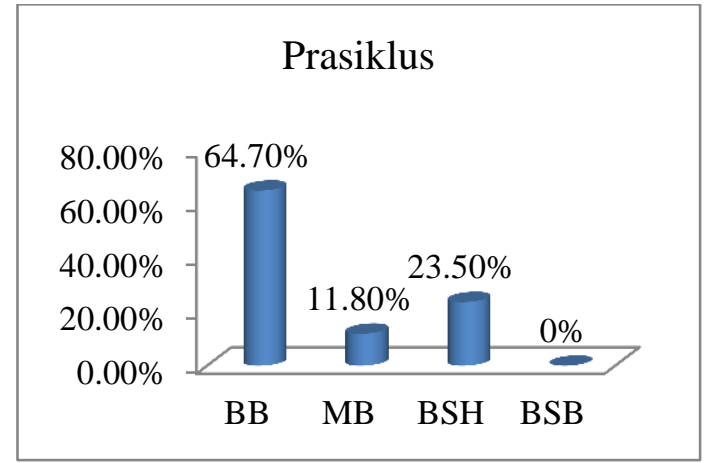

Grafik 1 Kemampuan Melipat Anak Pra Tindakan

Keterangan :

$\begin{array}{ll}\text { BB } & \text { : Belum Berkembang } \\ \text { MB } & \text { : Mulai Berkembang } \\ \text { BSH } & \text { : Berkembang Sesuai Harapan } \\ \text { BSB } & \text { : Berkembang Sangat Baik }\end{array}$

Hasil kemampuan awal menyebutkan bahwa kemampuan melipat anak kelompok B mendapatkan perolehan data yaitu anak mendapat kriteria penilaian berkembang sesuai harapan sebanyak 4 anak $(23,5 \%)$, mulai berkembang 2 anak $(11,8 \%)$ dan belum berkembang 11 anak (64,7\%) yang masih memerlukan bimbingan.

\section{Siklus I}

Hasil observasi pertemuan pertama memperoleh data berupa angka persentase kemampuan melipat melalui kegiatan melipat kertas dengan kertas warna-warni. Hasil observasi pertemuan pertama dengan menggunakan instrumen lembar observasi menyebutkan bahwa kemampuan melipat anak kelompok B yaitu anak yang memperoleh penilaian dengan kriteria berkembang sesuai harapan sebanyak 6 anak $(35,3 \%)$ dari jumlah keseluruhan 17 anak, mulai berkembang 2 anak (11,8\%) dan belum berkembang 9 anak (52,9\%).

Hasil observasi pertemuan kedua diperoleh data berupa angka persentase kemampuan melipat melalui kegiatan melipat kertas warna-warni. Hasil observasi pada pertemuan kedua dengan menggunakan instrumen lembar observasi menyebutkan bahwa kemampuan melipat anak kelompok B yaitu anak yang memperoleh penilaian dengan kriteria sesuai harapan sebanyak 8 anak (47\%), mulai berkembang 3 anak $(17,7 \%)$ dan belum berkembang 6 anak (35,3\%) dan masih memerlukan bimbingan dan motivasi.

Hasil observasi kemampuan melipat pada Siklus I dari pertemuan pertama dan kedua di setiap pertemuannya mengalami peningkatan hasil persentase. Perolehan persentase anak yang mampu menunjukkan kemampuan melipat kertas warna-warni dengan baik pada Siklus I yaitu sebesar $47 \%$ dari 17 anak yang diteliti. Perolehan persentase tersebut belum dapat dikatakan berhasil karena hasil belum mencapai pada angka persentase keberhasilan yaitu sebanyak 80\% dari 17 anak mampu menunjukkan kemampuan melipat dengan baik melalui kegiatan melipat kertas warna-warni. 
Untuk itu peneliti perlu melakukan penelitian kembali pada siklus II.

Tabel 3 Rekapitulasi Peningkatan Kemampuan Melipat Siklus I

\begin{tabular}{cccccc}
\hline No & Penil & \multicolumn{2}{c}{ Pertemuan } & \multicolumn{2}{c}{ Pertemuan } \\
& aian & \multicolumn{2}{c}{ Pertama } & \multicolumn{2}{c}{ Kedua } \\
& & Jml & $\%$ & \multicolumn{2}{c}{ Jml } \\
& & Anak & \multicolumn{3}{c}{ Anak } \\
\hline 1 & BB & 9 & $52,9 \%$ & 6 & $35,3 \%$ \\
2 & MB & 2 & $11,8 \%$ & 3 & $17,7 \%$ \\
3 & BSH & 6 & $35,3 \%$ & 8 & $47 \%$ \\
4 & BSB & 0 & $0 \%$ & 0 & $0 \%$ \\
\hline
\end{tabular}

Berdasarkan perolehan persentase kemampuan melipat anak Kelompok B Siklus I dapat dilihat pada grafik berikut ini:

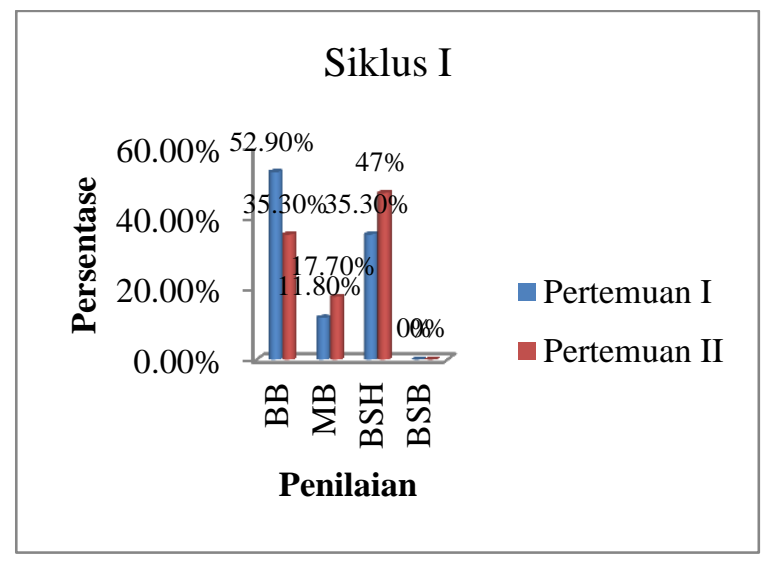

Grafik 2 Persentase Kemampuan Melipat Siklus I

Keterangan :

$\begin{array}{ll}\text { BB } & \text { : Belum Berkembang } \\ \text { MB } & \text { : Mulai Berkembang } \\ \text { BSH } & \text { : Berkembang Sesuai Harapan } \\ \text { BSB } & \text { : Berkembang Sangat Baik }\end{array}$

Refleksi yang dilakukan oleh peneliti berupa evaluasi terhadap proses pembelajaran yang telah dilakukan dalam satu siklus. Masalah yang dibahas adalah masalah-masalah yang muncul pada pelaksanaan tindakan Siklus I. Berdasarkan hasil pembahasan ditemukan beberapa kendala pada Siklus I, anak mengalami kesulitan saat mengikuti tahapan-tahapan melipat, ini disebabkan peneliti dalam mengajarkan cara melipat kertas terlalu cepat. Penggunaan kertas lipat yang kaku membuat hasil lipatan kertas sulit untuk diperbaiki arah lipatannya, meninggalkan bekas lipatan yang susah untuk dikembalikan lagi seperti kondisi semula, sehingga anak cenderung malas untuk meneruskan melipat kertas.

Tindakan penelitian pada Siklus I masih perlu perbaikan, diharapkan pada Siklus II dapat lebih baik dalam meningkatkan kemampuan melipat anak Kelompok B. Perlu adanya rencana langkah-langkah perbaikan yang akan digunakan pada Siklus II, dalam memberikan arahan melipat, peneliti mengajarkan tahap demi tahap secara berlahan sehingga anak akan mudah untuk melihat arahan dari peneliti saat membimbing melipat kertas. Kegiatan melipat kertas warna-warni menggunakan jenis kertas lipat yang umum dipakai dan yang mempunyai dua sisi warna yang sama dan mempunyai dua sisi warna berbeda. 
Peneliti menyiapkan kertas hvs putih untuk menempel hasil lipatan anak.

\section{Siklus II}

Hasil observasi pertemuan pertama memperoleh data berupa angka persentase kemampuan melipat dengan media kertas warna-warni. Hasil observasi pertemuan pertama dengan menggunakan instrumen lembar observasi menyebutkan bahwa kemampuan melipat anak kelompok B yaitu anak yang memperoleh penilaian dengan kriteria berkembang sangat baik sebanyak 4 anak $(23,5 \%)$ dari jumlah keseluruhan 17, berkembang sesuai harapan sebanyak 7 anak (41,2\%), mulai berkembang 4 anak $(23,5 \%)$ dan belum berkembang 2 anak (11,8\%).

Hasil observasi pertemuan kedua diperoleh data berupa angka persentase kemampuan melipat melalui kegiatan melipat kertas warna-warni. Hasil observasi pada pertemuan kedua dengan menggunakan instrumen lembar observasi menyebutkan bahwa kemampuan melipat anak kelompok B yaitu anak yang memperoleh penilaian dengan kriteria berkembang sangat baik sebanyak 5 anak $(29,4 \%$, berkembang sesuai harapan sebanyak 10 anak (58,8\%), mulai berkembang 1 anak $(5,9 \%)$ dan belum berkembang 1 anak (5,9\%) dan masih memerlukan bimbingan dan motivasi.
Hasil observasi kemampuan melipat pada Siklus II dari pertemuan pertama dan kedua di setiap pertemuannya mengalami peningkatan hasil persentase. Perolehan persentase anak yang mampu menunjukkan kemampuan melipat dengan baik pada Siklus II yaitu sebesar $88,2 \%$ dari 17 anak yang diteliti. Perolehan persentase tersebut dapat dikatakan berhasil karena hasil sudah mencapai pada angka persentase keberhasilan yaitu sebanyak $80 \%$ dari 17 anak mampu menunjukkan kemampuan melipat dengan baik melalui kegiatan melipat kertas warna-warni.

Tabel 4 Rekapitulasi Peningkatan Kemampuan Melipat Siklus II

\begin{tabular}{cccccc}
\hline No & Penilaian & \multicolumn{2}{c}{$\begin{array}{c}\text { Pertemuan } \\
\text { Pertama }\end{array}$} & \multicolumn{2}{c}{ Pertemuan Kedua } \\
& & Jml & $\%$ & Jml & $\%$ \\
& & Anak & & Anak & \\
\hline 1 & BB & 2 & $11,8 \%$ & 1 & $5,9 \%$ \\
2 & MB & 4 & $23,5 \%$ & 1 & $5,9 \%$ \\
3 & BSH & 7 & $41,2 \%$ & 10 & $58,8 \%$ \\
4 & BSB & 4 & $23,5 \%$ & 5 & $29,4 \%$ \\
\hline
\end{tabular}

Berdasarkan perolehan persentase kemampuan melipat anak Kelompok B Siklus II dapat dilihat pada grafik berikut ini: 


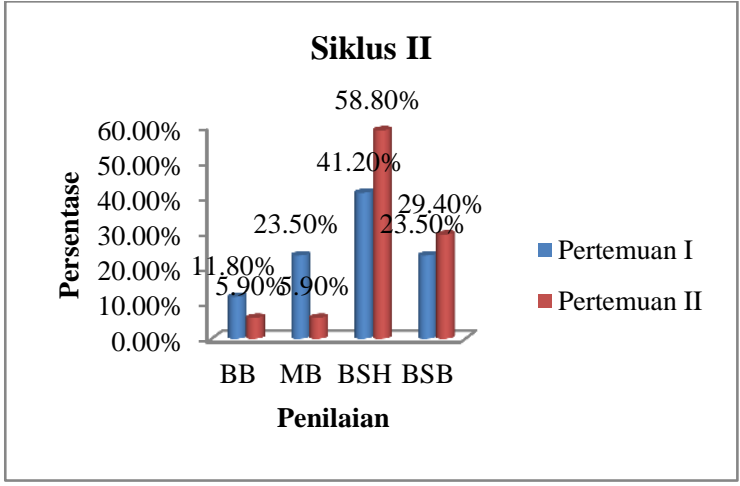

Grafik 3 Persentase Kemampuan Melipat Siklus II

Keterangan :

$\begin{array}{ll}\text { BB } & \text { : Belum Berkembang } \\ \text { MB } & \text { : Mulai Berkembang } \\ \text { BSH } & \text { : Berkembang Sesuai Harapan } \\ \text { BSB } & \text { : Berkembang Sangat Baik }\end{array}$

Refleksi pada penelitian ini adalah evaluasi terhadap tindakan yang dilakukan selama Siklus II. Berdasarkan hasil evaluasi, kegiatan melipat menggunakan media kertas warna-warni pada anak Kelompok B TK Dharma Wanita I Malebo Kandangan mampu meningkatkan kemampuan melipat anak. Perbaikan yang dilakukan pada Siklus II sangat mempengaruhi perubahan kemampuan melipat pada Kelompok B, dengan menambah perlakuan yaitu memberi kesempatan kepada anak untuk mengulang kembali melipat kertas agar anak memiliki keterampilan sendiri membuat lipatan tanpa bimbingan dari peneliti. Hasil observasi pada Siklus II menunjukkan peningkatan kemampuan melipat anak Kelompok B telah mencapai indikator keberhasilan yaitu sebesar 88,2\% .
Hasil penelitian pada Siklus I dan II menunjukkan adanya peningkatan kemampuan melipat anak Kelompok B yang mengalami peningkatan pada setiap pertemuan. Berikut adalah hasil penelitian kemampuan melipat pada anak Kelompok B TK Dharma Wanita I Malebo Kandangan Temanggung disajikan dalam bentuk tabel:

Tabel 5. Hasil Rekapitulasi Kemampuan Melipat Pratindakan, Siklus I dan Siklus II

\begin{tabular}{cccccccc}
\hline No & Peni & \multicolumn{2}{c}{ Pra Siklus } & \multicolumn{2}{c}{ Siklus I } & \multicolumn{2}{c}{ Siklus II } \\
& laian & Jml & $\%$ & Jml & $\%$ & Jml & $\%$ \\
\hline 1 & BB & 11 & $64,7 \%$ & 6 & $35,3 \%$ & 1 & $5,9 \%$ \\
2 & MB & 2 & $11,8 \%$ & 3 & $\% 17,4$ & 1 & $5,9 \%$ \\
3 & BSH & 4 & $23,5 \%$ & 8 & $47 \%$ & 10 & $58,8 \%$ \\
4 & BSB & 0 & $0 \%$ & 0 & $0 \%$ & 5 & $29,4 \%$ \\
\hline
\end{tabular}

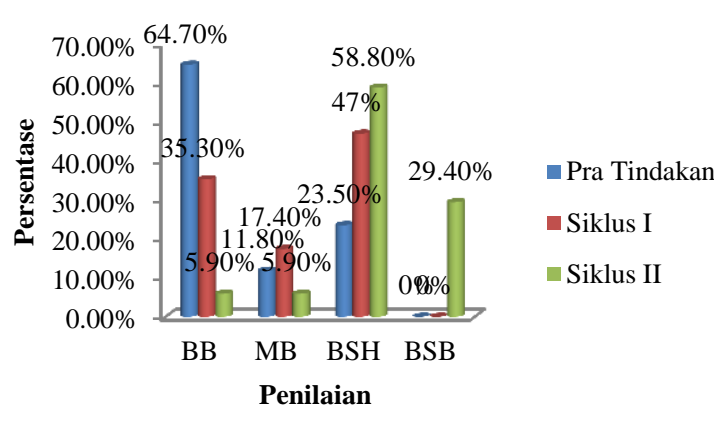

Grafik 4. Hasil Rekapitulasi Kemampuan Melipat Pratindakan, Siklus I dan Siklus II

Berdasarkan data yang disajikan melalui grafik di atas, diketahui bahwa terjadi peningkatan yang sigifikan pada Siklus II yaitu kemampuan melipat pada anak Kelompok B di TK Dharma Wanita I Malebo Kandangan Temanggung yaitu mencapai $\geq 80 \%, \quad$ dimana kriteria kemampuan anak mencapai persentase 
sebesar $88,2 \%$. Penelitian ini dikatakan berhasil karena telah mencapai indikator keberhasilan yang telah ditentukan yaitu sebesar $80 \%$.

Tindakan pada penelitian ini dilakukan melalui kegiatan melipat kertas warna-warni. Melipat kertas adalah suatu bentuk karya seni atau kerajinan tangan yang umumnya dibuat dari bahan kertas, dengan tujuan untuk menghasilkan beraneka ragam bentuk maianan, hiasan, benda fungsional, alat peraga, dan kreasi lainnya (Sumanto, 2005: 99-100). Selama penelitian berlangsung, anak-anak antusias dalam mengikuti kegiatan melipat kertas warna-warni. Bagi anak usia Taman Kanak-kanak kegiatan melipat kertas merupakan salah satu bentuk kegiatan bermaian kreatif yang menarik dan menyenangkan. Melalui kegiatan melipat kertas dapat mengembangkan kompetensi pikir, imajinasi, dan rasa seni. Kegiatan melipat kertas juga dapat meningkatkankan keterampilan motorik halus anak, seperti melatih gerak otot tangan sehingga anak memiliki kemampuan untuk memegang pensil, meniru membuat bentuk huruf atau angka, menggambar dan lain sebagainya.

Kemampuan melipat kertas pada anak Kelompok B mengalami peningkatan karena diberikan stimulus berupa kegiatan melipat dengan menggunakan kertas warna-warni, dimana anak langsung mempraktekkan melipat kertas menjadi bentuk benda. Peserta didik akan cepat mengalami peningkatan kemampuannya jika dalam proses pembelajaran anak terlibat secara langsung dalam kegiatan pembelajaran. Berdasarkan penjelasan di atas menegaskan bahwa penggunaan media kertas warna-warni dapat meningkatkan kemampuan melipat anak, karena kertas yang digunakan bermacam-macam warnanya sehingga menarik perhatian anak, selain itu anak terlibat secara langsung dalam pembelajaran.

\section{Pembahasan}

Penelitian ini bertujuan untuk meningkatkan kemampuan melipat anak menggunakan media kertas warna-warni. Menurut teori behavioristik (Asri Budiningsih, 2004: 20), belajar adalah perubahan tingkah laku sebagai akibat dari adanya interaksi antara stimulus dan respon. Dengan kata lain, belajar merupakan bentuk perubahan yang dialami siswa dalam hal kemampuannya untuk bertingkah laku dengan cara yang baru sebagai hasil interaksi dan respon. Terkait dengan teori behavioristik yang mengedepankan adanya stimulus dan respon maka, dalam penelitian ini stimulus yang diberikan berupa kegiatan melipat menggunakan media kertas warna-warni 
dan respon yang muncul yaitu kemampuan melipat pada anak Kelompok B mengalami peningkatan.

Media kertas warna-warni terbukti mampu meningkatkan kemampuan melipat pada anak Kelompok B TK Dharma Wanita I Malebo Kandangan Temanggung Semester II Tahun Pelajaran 2017/2018. Hal ini dibuktikan dengan adanya data yang diperoleh selama penelitian yang mengalami peningkatan pada setiap pertemuan.

Adapun langkah-langkah kegiatan melipat menggunakan media kertas warnawarni dalam penelitian ini adalah peneliti dalam memberikan peragaan langkahlangkah melipat pada anak menggunakan peraga yang ukurannya lebih besar dari kertas lipat yang digunakan oleh anak yang bertujuan agar dalam praktek melipat kertas, peserta didik dapat melihat lebih jelas tahapan-tahapan dalam melipat.

Setiap tahapan melipat yang sudah dibuat oleh anak hendaknya diberikan penguatan misalnya "rapikan lipatan" yang sudah dibuat dan sebagainya. Bila anak sudah selesai membuat bentuk lipatan, anak diberi reward atau pujian dan diberi kesempatan untuk mengulangi melipat lagi agar setiap anak memiliki keterampilan sendiri membuat lipatan tanpa bantuan bimbingan dari guru.
Pada tabel hasil penelitian di atas dapat dikatakan bahwa penggunaan media kertas warna-warni dapat meningkatkan kemampuan melipat pada anak kelompok B TK Dharma Wanita I Malebo Kandangan Temanggung Semester II Tahun Pelajaran 2017/2018, dengan dibuktikan adanya hasil diskriptif persentase ketuntasan belajar yaitu dari kondisi awal jumlah anak yang mendapat kriteria penilaian berkembang sesuai harapan sebanyak 4 anak atau 23,5\%, meningkat menjadi 8 anak atau $47 \%$ pada Siklus I, dan pada Siklus II meningkat sebanyak 10 anak atau 58,8\% dengan kriteria penilaian berkembang sesuai harapan dan 5 anak atau 29,4\% dengan penilaian berkembang sangat baik.

Setelah dilakukan pembelajaran dengan mengikuti langkah-langkah pembelajaran yang dipaparkan oleh Sumanto (2005: 102), kemampuan melipat anak Kelompok B TK Dharma Wanita I Malebo Kandangan mengalami peningkatan. Begitu pula berdasarkan teori behavioristik dalam penelitian ini bahwa pemberian stimulus berupa kegiatan meliapat dengan media kertas warna-warni maka respon yang muncul yaitu meningkatnya kemampuan melipat pada anak Kelompok B TK Dharma Wanita I 
Malebo Kandangan Temanggung Semester II Tahun Pelajaran 2017/2018.

\section{SIMPULAN}

Berdasarkan hasil penelitian yang sesuai Berdasarkan hasil pengamatan dan analisi data yang diperoleh dari tindakan perbaikan pembelajaran antar siklus dalam penelitian tindakan kelas yang dilakukan melalui pembelajaran dapat ditarik kesimpulan bahwa dengan menggunakan media kertas warna-warni dapat meningkatkan kemampuan melipat pada anak Kelompok B TK Dharma Wanita I Malebo Kandangan Temanggung. Pengembangan dalam kegiatan melipat dengan memilih media kertas warna-warni yang menarik bagi anak, membuat bentuk lipatan yang menarik dan unik, serta melibatkan anak dalam kegiatan, sangat membantu anak dalam meningkatkan kemampuan melipat.

Pada tabel hasil penelitian di atas dapat dikatakan bahwa penggunaan media kertas warna-warni dapat meningkatkan kemampuan melipat pada anak kelompok B TK Dharma Wanita I Malebo Kandangan Temanggung Semester II Tahun Pelajaran 2017/2018, dengan dibuktikan adanya hasil diskriptif persentase ketuntasan belajar yaitu dari kondisi awal jumlah anak yang mendapat kriteria penilaian berkembang sesuai harapan sebanyak 4 anak atau 23,5\%, meningkat menjadi 8 anak atau $47 \%$ pada Siklus I, dan pada Siklus II meningkat sebanyak 10 anak atau 58,8\% dengan kriteria penilaian berkembang sesuai harapan dan 5 anak atau 29,4\% dengan penilaian berkembang sangat baik.

Peningkatan kemampuan melipat pada anak kelompok B TK Dharma Wanita I Malebo mengalami peningkatan sebesar 64,7\% dari pra siklus ke Siklus II, ditandai dengan anak mampu melipat kertas mengikuti petunjuk lebih dari 7 lipatan dan mampu melipat kertas menjadi bentuk sederhana dengan rapi.

\section{DAFTAR PUSTAKA}

Ahmad, Susanto. (2013). Teori Belajar dan Abdurrahman, J. 2005. Tahapan Mendidik Anak. Bandung: Irsyad Baitus Salam

Aprisa, Desy. (2013). Metode Pembelajaran Seni Rupa Di TK (on line) tersedia di: http://desyaprisa.blogspot.com/2013/ 03/metode-pembelajaran-seni-rupadi-tk.html

Arikunto, Suharsimi. (2005). Prosedur Penelitian Suatu Pendekatan Praktik. Jakarta : PT Rineka Cipta (2007). Prosedur Penelitian Suatu Pendekatan Praktis. Jakarta: Rineka Cipta.

Budiningsih, C.Asri. (2008). Belajar dan Pembelajaran. Jakarta: Rineka Cipta. 
Christianti, Martha. (2014). Melipat Kertas Untuk Anak Usia Dini. Modul. Yogyakarta: Universitas Negeri Yogyakarta.

Depdiknas. (2009). Permendiknas No. 58/2009 tentang Standar Tingkat Pencapaian Perkembangan. Jakarta:Depdikbud

Ismayanti, Fajar. (2012). Manfaat Origami. http://sanggar-origamiindonesia.com/10-manfatorigami.html.

Iskandar. (2008). Metodologi Penelitian Pendidikan Dan Sosial (Kuantitatif Dan Kulitatif). Jakarta: Gaung Persada Press.

Klub Origami Indonesia. (2012). Jenisjenis Kertas Origami. http://origamiindonesia.com/jenis-jenis-kertasdalamorigami-kind-ofpaper.html.

Munandar, U. (1985). Mengembangkan Bakat dan Kreativitas Anak Sekolah. Jakarta: PT Gramedia.

Mutiah, Diana. (2010). Psikologi Bermain Anak Usia Dini. Jakarta: Prenada Media Group.

Novikasari, Meli, dkk. (2012). Mewarnai, Menggunting, Menempel ( $3 m$ ) Dan Melipat (on line) tersedia di: http://melyloelhabox.blogspot.com/ 2012/10/mewarnai-mengguntingmenempel-3m-dan.html

Pandiangan, Ester. (2009). Segudang Manfaat Origami Untuk Anak (on line) tersedia di: http://mayahirai.com/2009/08/12/seg udang-manfaat-origami-untuk-anak
Sanjaya, Wina. (2011). Penelitian Tindakan Kelas. Jakarta: Kencana Prenada Media Group

Setiani, Sri. (2007). Bermain dan Permainan Anak. (Editor: B.E.F. Montolalu). Jakarta: Universitas Terbuka

Sugiyono. (2009). Metode Penelitian Kualitatif, Kuantitatif, Dan $R \& D$. Bandung: Alfabeta.

Sumanto. (2005). Pengembangan Kreativitas Senirupa Anak Tk. Jakarta: Departemen Pendidikan Nasional, Direktorat Jenderal Pendidikan Tinggi, Direktorat Pembinaan Pendidikan Tenaga Kependidikan dan Ketenagaan Perguruan Tinggi.

Sumantri. (2005). Pengembangan Keterampilan Motorik Anak Usia Dini. Jakarta: Dinas Pendidikan

Supardi. (2009). Penelitian Tindakan Kelas. Jakarta : Bumi Aksara

Suwandi, Sarwaji. (2010). Penelitian Tindakan Kelas (PTK) Dan Penulisan Karya Ilmiah. Surakarta: Yuma Pustaka. 